\title{
Um conceito de Poética
}

\author{
Nuno Júdice \\ (Universidade Nova de Lisboa)
}

\section{RESUMO}

A partir das distinções entre linguagem poética e linguagem comum, o artigo discute as distinções entre poesia e literatura sob a perspectiva de alguns poetas e críticos. Ao fim, articula esta especificidade da poesia ao modelo da "recriação perpétua" (perpetuum mobile) como recurso neo-barroquista que regressa de forma renovada na produção de poética atual.

PALAVRAS-CHAVE: poética; literatura; neo-barroquismo

\section{RÉSUMÉ}

A partir des distinctions entre langue poétique et langue commune, l'article discute des distinctions entre poésie et littérature selon la perspective de quelques poètes et critiques. À la fin, il met en rapport cette spécificité de la poésie et la "recréation perpétuelle" (perpetuum mobile) comme faisant partie d'une esthétique neo-baroque qu'on trouve renouvelée dans la production poétique actuel.

MOTS-CLÉS: poétique ; littérature; neo-baroque 
A poesia é uma forma construída a partir da deslocação - passagem de um objecto a outro, de uma imagem a outra, de uma ideia a outra. É por isso no poema que a linguagem encontra a sua realização mais completa no jogo de pensamento que é o exercício analógico. O que é característico deste raciocínio é a leitura "prospectiva", em que o significado é diferido para além da palavra literal - saber que a imagem dita no poema é a que está para além do que é expresso; e isso conduz a essa leitura diferida que é simultânea com a leitura actual, ou seja, o poema contém em si o mesmo e o outro da imagem.

Tomemos o exemplo de sol, significando vida; ou de cipreste, significando morte: a velocidade de deslocação de uma imagem para outra é imediata, e o transporte semântico é dado pela simultaneidade da elipse (redução ou concentração de vários significados num único objecto) e do transporte metafórico, em que existe uma economia expressiva e lacunas que o leitor terá de preencher.

Há um apelo ao imaginário do leitor e à sua capacidade de preencher esses lapsos narrativos que só existem porque o texto os inscreve numa estrutura em que os grandes esquemas analógicos estão subjacentes a qualquer invenção, na linha de Jung de que não há inconsciente pessoal mas colectivo, naquilo que Gaston Bachelard irá designar como complexos culturais.

No poema há então uma emergência de imagens que decorrem dessa radicação do processo formativo do poético numa psique colectiva, que é a matriz do pensamento e da estrutura antropológica do imaginário. Podemos usar, de acordo com Ítalo Calvino, as imagens do cristal e da chama para designar duas formas diversas da figura poética:

a chama (a iluminação de Rimbaud) que acende brilhos sucessivos;

o cristal - a imagem que polariza e fixa uma variedade de sentidos, indo no sentido da totalidade que é o símbolo.

É também a diferença entre o estilo metafórico, mais aberto e sempre em movimento - o poeta-vidente - e o estilo alegórico, em que se procura definir um quadro de significação última, em que a abertura está limitada por esse valor semântico final do texto.

O que é próprio da linguagem poética é que, fazendo parte dessa esfera meta-expressiva, integra também o quotidiano da expressão comum dado que impede que o discurso se torne monológico - e é o factor dialógico, introduzindo o outro (o receptor) no plano comunicacional que suscita uma troca (o factor da economia discursiva que está subjacente ao sistema linguístico), obrigando a que o texto não seja unívoco, pedindo uma interpretação mesmo nas suas expressões mais simples, a partir de uma contextualização em que nem tudo o que é dito é evidente se não se tiver em conta esse dizer em situação.

Acabamos por chegar sempre à mesma questão: o que é a poesia? E isto leva-nos para a procura de uma definição de poética, que vem dos antigos, mas que se prolonga para lá das épocas: poética é o que se distingue de um uso normal - prosaico e banal - da linguagem. Na poesia, as palavras distinguem-se pelo que são, e pela atenção a que nos obrigam tanto em relação ao sentido como à entoação, à música, ao acordo que delas nasce e que produz uma sensação de harmonia que se sobrepõe a tudo o resto. Lembremos a "Art Poétique" de Verlaine: 
De la musique avant toute chose,

Et pour cela préfère l'Impair

Plus vague et plus soluble dans l'air,

Sans rien en lui qui pèse ou qui pose.

\section{$(\ldots)$}

Que ton vers soit la bonne aventure

Eparse au vent crispé du matin

Qui va fleurant la menthe et le thym!...

Et tout le reste est littérature.

Neste poema que está na base da estética simbolista vamos encontrar uma oposição que se consagrou entre "poesia" e "literatura". Ruy Belo vai concretizar esta oposição numa subvalorização do literário (em sentido pejorativo) contraposto ao poético:

O poeta, embora culto e senhor da sua técnica, parte da realidade ou - como disseram os clássico e nós podemos voltar a dizer - imita a natureza. O literato parte quase sempre de um ou vários livros, é imitador de uma imitação. Daí provém a palidez das suas palavras, a pouca convicção e a arbitrariedade de tudo quanto diz. O poeta diz uma coisa onde nenhuma outra poderia dizer e di-lo com as únicas palavras possíveis, o literato fala por falar e nas palavras se compraz. (BELO, 1969, p. 79)

Distingue Ruy Belo o que vai buscar a sua fonte à literatura, o que não tem por trás das suas palavras uma experiência, algo de concreto num real que, no entanto, não é utilizado de modo final (descrever a realidade, ir ao encontrado dela) mas substancial (dar corpo verbal a essa realidade). O poema, por isso, não precisa de recorrer ao extra-poético para ser total no seu mundo:

Quando o poeta, no seio de um poema, profere a palavra árvore, o que faz não é utilizar um conceito a que houvesse sacrificado todas as opulentas árvores de pássaros que diariamente encontra no seu caminho. Em vez de se sujeitar à abstracção que o conhecimento pelos meios lógicos impõe, é como se utilizasse uma verdadeira árvore, com os seus pássaros, as suas folhas, a sua sombra, a sua tristeza ou alegria. Apenas se limita a dar a essa árvore uma nova vizinhança: ou Deus, ou a infância, ou - que sei eu? - talvez o pressentimento da morte. Como é que ele conseguirá criar assim uma árvore tão viva? Pegando na palavra em si, rompendo talvez as suas relações habituais com outras palavras, dando-lhe outras novas, que, através do choque, da surpresa, do inaudito, a cerquem e iluminem de determinada maneira e a rodeiem de silêncio. (BELO, 1969, pp. 112-113)

Quase que lembraria um poema de Mário Dionísio para explicitar o modo como se opera esta transição (transacção) real-poético: 
Tudo começa num ramo

de oliveira

aberto em braços de que saem braços

luxurioso caprichosos

vagarosos de abraços deslaçados

nos espaços

Prende-se nele a brisa em mil requebros lassos

complacente

Um bago branco Um vago azul

mil bafos de euforia

$\mathrm{Na}$ serena folhagem transparente

solta-se quente aberta em leque

uma quase alegria

comprometida e inocente (DIONÍSIO, 1965)

A libertação do verso decorre de uma analogia com o próprio crescimento da árvore, na sugestão de ramos curtos e longos onde tem início a passagem para o plano musical, num jogo aliterativo que se organiza como uma folhagem sonora; uma sugestão visual, cinestésica, na visão do branco e do azul; e finalmente a personificação da própria árvore ao soltar-se dela uma "alegria" a que se junta o qualificativo de "inocente". O que é significativo neste processo é que a imagem vai sendo envolvida por uma outra realidade que a transfigura ou desloca do seu espaço conceptual, abstracto, para um novo plano de significação em que a palavra representa a realidade para que remete, ou seja, não temos esse objecto (a oliveira) como referente mas sim todo o complexo de ramificações lógicas, semânticas e musicais que o poema descreve.

É esta totalidade que corresponde a uma poética tal como Ruy Belo a descreve e António Ramos Rosa designa de um modo mais essencial, na distinção entre o poético e o literário:

A poesia, seja num verdadeiro verso, seja num poema, tem uma densidade própria, uma existência. Existência, num sentido estético, pressupõe coerência interna, individualidade, unicidade, o que é por si mesmo. A densidade é esta estrutura complexa e una, o dado inicial da percepção do poema. Através da organização de signos e sons, a impulsão criadora repercutese, algo da criatividade inicial se propaga e transmite ao leitor. Um poema é, assim, um princípio de vida. Daí que a cada leitura se comparticipe, de algum modo, da criação poética. (ROSA, 1962, p. 33)

Daqui decorre a importância do leitor - ou da leitura -, não tanto no sentido da sua percepção e da sua presença no instante da escrita, mas no momento da abertura semântica que decorre da sua apreensão. Esta ideia de um "princípio de vida" vai fazer com que, a cada leitura, o poema renasça em sentidos diferentes, em vivências sempre alargadas a partir do horizonte que cada leitura lhe pode conferir, o que constitui um enriquecimento permanente do espaço poético. Se Ruy Belo sugere que "o leitor deve percorrer, em sentido inverso, o mesmo caminho que o poeta percorreu” (BELO, 1969, p. 89), não é 
menos certo que o caminho da interpretação não é um caminho regressivo, embora aí também se encontrem sem dúvida algumas chaves dos códigos metafóricos e imagéticos, mas progressivo, indo para além do que o poema constitui como objecto presente, e procurando encontrar as ramificações que nascem de todo o complexo estrutural e organizativo das imagens actuais.

O que distingue, então, o poético do "literário", na expressão de Ruy Belo, é esta dinâmica autotélica do poema: se todo o seu movimento envolve uma cosmogonia em que mundo e palavras orbitam a partir de uma atracçãorepulsa que constitui um equilíbrio insusceptível de ruptura, o eixo desse movimento assenta no objecto que é o poema, aonde se regressa de cada vez que uma tentação ex-cêntrica nos tenta levar para fora desse espaço.

No fechamento do espaço poético, o que remete para um exterior torna-se acessório, sendo essa tensão objectiva do corpo verbal o elemento determinante da "captação semântica", ou seja, o sentido do poema não é algo que possa nascer de um "fora do poema", uma significação que lhe seja anterior, mas a cada leitura há um mecanismo produtor de sentido(s) que é posto em funcionamento, e adquire uma característica renovável.

Podemos, por este motivo, incluir o poema dentro do que se chamaria uma recriação perpétua (perpetuum mobile), recuperando o projecto barroco que nasce da glosa e da variação, repetidos até à exaustão. É esta passagem do sujeito para o objecto, no plano da construção de sentido, que caracteriza essa estética, criando um espaço vazio, ou um não espaço, dentro do espaço do poema, onde estaria o sujeito na poesia tradicional, na poesia clássica ou romântica. É toda a diferença entre duas estéticas que aqui se situa; e aquilo que uma crítica psicológica ou estilística iria procurar - as marcas do sujeito no poema - não faz sentido quando estamos perante um texto barroco.

Imporá, no entanto, não reduzir esta estética a um simples formalismo. É algo de mais profundo, dado que implica efectuar uma transferência do sujeito para o objecto, e projectar no objecto a capacidade de expressão de um sujeito outro, que está para além do próprio texto, no lugar do leitor, e não antes, no lugar do autor. Esta transferência do autor para o leitor como substância subjectiva é sem dúvida uma marca decisiva deste tipo de expressão; e é interessante verificar que não se limita à poesia, podendo também haver prosa, ficção, onde o sujeito autoral procura retirar-se para dar todo o papel construtivo do sentido ao próprio texto, como se verifica por exemplo em muitos textos de Gonçalo M. Tavares, feitos a partir de uma glosa (real ou simulada) de autores diversos (de Barthes, Walser, Beckett, a Valéry, entre outros), numa linha que se pode associar ao projecto Oulipo.

Com tonalidades diferentes, este neo-barroquismo é comum a diversos autores actuais, e resulta da importância crescente que o trabalho formal tem vindo a adquirir, num corte com o projecto realista que corresponde ao renascimento da ficção portuguesa das últimas décadas do século XX. Na poesia, um dos casos mais interessantes a estudar nesta linha é o de Manuel Gusmão, embora a presença do sujeito seja algo que não pode ser posta de lado - no entanto, o lado intelectual e reflexivo desse sujeito, questionando e questionando-se, faça dele muitas vezes uma realidade mais intelectual do que vivencial.

Regresso ao barroco, então, mas a um barroco como centro de interrogação sobre as fronteiras dos mundos da razão e da imaginação, da luz e da sombra, da presença e da ausência, e não ao simples jogo de conceitos e de 
imagens, a um mero exercício de virtuosismo formal. Não é, portanto, um regresso, mas um avanço em direcção a uma ruptura com aquilo que foram as estéticas do século XX, e as dominantes realista ou romântica que se foram sucedendo ao longo desse período.

\section{REFERÊNCIAS BIBLIOGRÁFICAS}

BELO, Ruy. Na senda da poesia. Lisboa: União Gráfica, 1969

ROSA, António Ramos. Poesia, liberdade livre. Lisboa: Livraria Morais Editora, 1962.

DIONíSIO, Mário. Memória de um pintor desconbecido. Col. Poetas de hoje. Lisboa: Portugália, 1965. 